\title{
Through a Glass Darkly: English Common Law Seen through the Lens of the Göttingische Gelehrte Anzeigen (Eighteenth Century)
}

\author{
CARSTEN FISCHER
}

\begin{abstract}
Introduction
In the nineteenth century, English law attracted the attention of an increasing number of German legal scholars. Their perspectives and interests varied. While some, fuelled by the discourses of the Historical School of Law, looked for 'genuinely Germanic' legal sources or concepts, ${ }^{1}$ others were eager to learn via comparison, ${ }^{2}$ while yet others were intent not on reflecting on their own legal system by way of a comparative detour, but rather on understanding a particular foreign legal system. ${ }^{3}$ One of the better known examples of this curious look abroad is the debate on 'Geschworenengerichte', or juries, led with particular

${ }^{1}$ On such early undertakings by the Germanistic branch of the Historical School of Law, see F. Ranieri, 'Eine frühe deutsche Übersetzung der "Commentaries on the Laws of England" von William Blackstone. Zugleich ein Beitrag zur Instrumentalisierung des Common law in der deutschen Germanistik des 19. Jahrhunderts', in T. J. Chiusi, T. Gergen, and H. Jung (eds.), Das Recht und seine historischen Grundlagen. Festschrift für Elmar Wadle zum 70. Geburtstag (Schriften zur Rechtsgeschichte, 139; Berlin, 2008), 875-99. The academic framework of the nascent Deutsches Privatrecht is analysed by D. Klippel, 'Das deutsche Privatrecht in der zweiten Hälfte des 18. Jahrhunderts', in H. P. Haferkamp and T. Repgen (eds.), Usus modernus pandectarum. Römisches Recht, Deutsches Recht und Naturrecht in der Frühen Neuzeit. Klaus Luig zum 70. Geburtstag (Cologne, Weimar and Vienna, 2007), 63-74, and K. Luig, 'Die Anfänge der Wissenschaft vom deutschen Privatrecht', Ius Commune, 1 (1967), 195-222. One of the earliest attempts at what can be called comparative Germanistic legal science is Johann Carl Heinrich Dreyer's De usu genuine iuris Anglo-Saxonici in explicando iure cimbrico et saxonico, liber singularis (Kiel, 1747); reviewed in GGA 1747, 582-3 (abbreviation explained below in n. 20). All translations in the present essay are by the author.

2 J. I. Gundermann, Richteramt und Advokatur in England mit Vergleichung continentaler Zustände (Munich, 1870).

3 See, for example, J. I. Gundermann, Englisches Privatrecht, 1. Theil: Die Common Law (Tübingen, 1864); vol. II ('2. Theil') was never published.
\end{abstract}


intensity in the 1840s by, to name but a few, Friedrich August Biener $(1787-1861),{ }^{4}$ Joseph Ignaz Gundermann ${ }^{5}$ and Rudolf von Gneist (1816-95), ${ }^{6}$ and then, a generation later, by Heinrich Brunner (1840-1915). ${ }^{7}$ Those with a penchant for constitutional or administrative law were, amongst other things, fascinated by the interaction of the monarchy, parliament and people of Great Britain. A good example of this approach would be Rudolf von Gneist, ${ }^{8}$ although Georg Friedrich Wilhelm Hegel's (1770-1831) thoughts on the British constitution, published in $1831,{ }^{9}$ could also be mentioned. Last but not least is Felix Liebermann (1851-1925), whose edition, translation and analysis of early and high medieval English legal sources is testament to this German academic Anglophilia. ${ }^{10}$ These debates were, of course, not confined to Germany, and often were closely followed by British scholars and added to British discourses. The inspiration Jacob Grimm (1785-1863) offered to John Mitchell Kemble (1807-57) or the high esteem in which Liebermann's efforts - and indeed his person - were held by

${ }^{4}$ F. A. Biener, Das englische Geschwornengericht (Leipzig, 1855); F. A. Biener, 'Die Criminaljury in England und ihre Zukunft', Kritische Zeitschrift für Rechtswissenschaft und Gesetzgebung des Auslandes, 25 (1853), 200-8; F. A. Biener, Begründung des Criminalrechts und Processes nach historischer Methode (Abhandlungen aus dem Gebiete der Rechtsgeschichte, 2; Leipzig, 1848), 9-183; F. A. Biener, 'Zur Geschichte der englischen Jury', Zeitschrift für deutsches Recht, 11 (1847), 57-65; F. A. Biener, Ueber die Einführung der Geschwornengerichte in England (Abhandlungen aus dem Gebiete der Rechtsgeschichte, 1; Leipzig, 1846), 7-54.

${ }^{5}$ Biographic data not available; J. I. Gundermann, Ueber die Einstimmigkeit der Geschwornen. Beitrag zu Geschichte und Verständnis des Schwurgerichts (Munich, 1849); J. I. Gundermann, Geschichte der Entstehung der Jury in England und deren leitender Gedanke. Ein germanistischer Versuch (Munich, 1847).

${ }^{6}$ R. (von) Gneist, Die Bildung der Geschworenengerichte in Deutschland (Berlin, 1849).

${ }^{7}$ H. Brunner, Die Entstehung der Schwurgerichte (Berlin, 1872).

${ }^{8}$ R. (von) Gneist, Das heutige englische Verfassungs- und Verwaltungsrecht, 2 vols. (Berlin, 1857-60); R. (von) Gneist, Englische Verfassungsgeschichte (Berlin and Heidelberg, 1882). Gneist's views of England have recently been analysed by A. Thier, 'Magna Carta in the German Discourse about English Constitutional Law between the Eighteenth and Early Twentieth Centuries', in C. Macmillan and C. Smith (eds.), Challenges to Authority and the Recognition of Rights, from Magna Charta to Modernity (Cambridge, 2018), 205-22, esp. 214-18, and F. L. Müller, 'Before "the West": Rudolf von Gneist's English Utopia', in R. Bavaj and M. Steber (eds.), Germany and 'the West': The History of a Modern Concept (Oxford, 2015), 152-66.

${ }^{9}$ G. W. F. Hegel, 'Über die englische Reformbill' (1831), in Georg Wilhelm Friedrich Hegel: Werke, vol. XI: Berliner Schriften 1818-1831, eds. E. Moldenhauer and K. M. Michel (Frankfurt am Main, 1986), 83-128.

10 See especially his magnum opus, Felix Liebermann, ed., Die Gesetze der Angelsachsen, 3 vols. (Halle/Saale, 1903-16). 
Frederick William Maitland and Thomas Frederick Tout ${ }^{11}$ are but two examples. $^{12}$

Nevertheless, even though these nineteenth-century discourses, lines of inquiry, legal scholars, and their monographs are reasonably well known, ${ }^{13}$ their prehistory is less so. We know very little about eighteenth-century German academic views of English and other British contemporary law. ${ }^{14}$ This is all the more deplorable since this century seems to be the age of 'first contact' in a legal academic context. ${ }^{15}$ The fact that this occurred in the eighteenth century is unsurprising: in cultural and academic terms (although one might consider the following something of an exaggeration), Great Britain had only occupied a place on the periphery of the perception of seventeenth-century German social, political and academic elites. However, this all changed with the Hanoverian succession to the British throne in 1714.

${ }^{11}$ On Liebermann, his work and its impact, see the contributions in S. Jurasinski, L. Oliver and A. Rabin (eds.), English Law Before Magna Carta: Felix Liebermann and Die Gesetze der Angelsachsen (Leiden, 2010).

12 For a bigger picture, see S. Berger and P. Lambert, 'Intellectual Transfers and Mental Blockades: Anglo-German Dialogues in Historiography', in S. Berger, P. Lambert and P. Schumann (eds.), Historikerdialoge, Geschichte, Mythos und Gedächtnis im deutschbritischen kulturellen Austausch 1750-2000 (Veröffentlichungen des Max-PlanckInstituts für Geschichte, 179; Göttingen, 2003), 9-61.

${ }^{13}$ On early German legal academic views on Great Britain and especially on English law, see for example C. Fischer, 'The Reception of Magna Carta in Early Modern Germany, c. 1650 1800', The Journal of Legal History, 37 (2016), 249-68; Thier, 'Magna Carta'; H. Dippel, 'Blackstone in Germany', in W. Prest (ed.), Blackstone and his Commentaries: Biography, Law, History (Oxford and Portland, OR, 2009), 199-214; H. C. Kraus, Englische Verfassung und politisches Denken im Ancien Régime 1689 bis 1789 (Munich, 2006), esp. 552-3; W. Pöggeler, Die deutsche Wissenschaft vom englischen Staatsrecht: Ein Beitrag zur Rezeptionsund Wissenschaftsgeschichte 1748-1914 (Comparative Studies in Continental and AngloAmerican Legal History / Vergleichende Untersuchungen zur kontinentaleuropäischen und anglo-amerikanischen Rechtsgeschichte, 16; Berlin, 1995); and the contributions in H. Coing and K. Nörr (eds.), Englische und kontinentale Rechtsgeschichte: ein Forschungsprojekt (Comparative Studies in Continental and Anglo-American Legal History / Vergleichende Untersuchungen zur kontinentaleuropäischen und angloamerikanischen Rechtsgeschichte, 1; Berlin, 1985). Regarding civilian common ground see H. Coing, 'Das Schrifttum der englischen Civilians und die kontinentale Rechtsliteratur in der Zeit zwischen 1550 und 1800', Ius Commune, 5 (1975), 1-55. Medieval and early modern civilian encounters with English law are analysed by $\mathrm{T}$. Rüfner, 'Continental Jurists and English Common Law', Glossae. European Journal of Legal History, 13 (2016), 627-35.

14 Along the same lines, see Ranieri, 'Eine frühe deutsche Übersetzung', 876-7. A notable exception in this regard is Kraus, Englische Verfassung, thoroughly analysing the constitutional discourses.

${ }^{15}$ For sporadic earlier Continental views see Rüfner, 'Continental Jurists and English Common Law', 627-35. 
Information about Great Britain, particularly about England, became more widely available in the Holy Roman Empire, for example via travel reports or translations of important works on British history. ${ }^{16}$

\section{Gelehrte Zeitschriften}

One of the often-overlooked features of this process of legal academic rapprochement is that it needed cultural midwives - translators. Until well into the latter half of the eighteenth century, very few people in the German territories read or spoke English. Translations of British literary products into better-known languages - Latin, French, Dutch, Italian and, of course, German - were vital. ${ }^{17}$ Besides this, for an academic exchange to take place, this literature needed to be inserted into the academic discourses of the day, as is still the case. Both purposes were served not only by more or less professional translators ${ }^{18}$ and by German

16 On Anglophilia, access to information about Great Britain and German views of Great Britain in the course of the eighteenth century, see Fischer, 'Reception of Magna Carta', 252-3; J. Willenberg, Distribution und Übersetzung englischen Schrifttums im Deutschland des 18. Jahrhunderts (Archiv für Geschichte des Buchwesens - Studien, 6; Munich, 2008), 19-94; W. J. Mommsen, 'Das Englandbild der Deutschen und die britische Sicht seit dem Ende des 18. Jahrhunderts', in H. Süssmuth (ed.), Deutschlandbilder in Dänemark und England, in Frankreich und in den Niederlanden (Schriften der Paul-Kleinewefers-Stiftung, 3; Baden-Baden, 1996), 215-34; S. Haikala, 'Britische Freiheit' und das Englandbild in der öffentlichen deutschen Diskussion im ausgehenden 18. Jahrhundert (Studia Historica Jyväskyläensia, 32; Jyväskylä, 1985), 31-38. On German Anglophilia on the eve of the French Revolution, see ibid., 39-58; W. J. Mommsen: 'Zur Entwicklung des Englandbildes der Deutschen seit dem Ende des 18. Jahrhunderts', in L. Kettenacker, M. Schlenke and H. Seier (eds.), Studien zur Geschichte Englands und der deutsch-britischen Beziehungen. Festschrift für Paul Kluke (Munich, 1981), 375-97.

17 Regarding German as a language of science, this is of course a process which has been reversed.

18 According to Willenberg, the ability to read English, much less to speak it, only spread in Germany in the second half of the eighteenth century; Willenberg, Distribution und Übersetzung, 72-94. For example, E. Foss, An Abridgment of Blackstone's Commentaries (London, 1821) was partly translated into German by H. F. C. von Colditz and, together with an introduction by Niels Nikolaus Falck, published in Schleswig in 1822/3. Ranieri highlights the problems German jurists had in translating English legal texts by examining the translation of a passage on the doctrine of consideration as well as Falck's thoughts on the use of precedents; Ranieri, 'Eine frühe deutsche Übersetzung', 894-8. For a case study of a linguistic intermediary, see C. W. Proescholdt, 'Johann Christian Hüttner (1766-1847): A Link between Weimar and London', in N. Boyle and J. Guthrie (eds.), Goethe and the English-Speaking World: Essays from the Cambridge Symposium for his 250th Anniversary (Studies in German Literature, Linguistics, and Culture; Rochester, NY and Woodbridge, 2002), 99-110. 
publishers and booksellers distributing publications, ${ }^{19}$ but also by gelehrte Zeitschriften - academic or learned journals.

From the late seventeenth century on, a plethora of such journals saw the light of day in Germany, with their creation and sometimes also their layout and emphases inspired by their foreign predecessors, especially the Parisian Journal des sçavans and the Philosophical Transactions of the Royal Society, both of which were first published in 1665. Beginning with the Acta Eruditorum (Leipzig, 1682-1732), edited by Gottfried Wilhelm Leibniz (1646-1716) himself, the following decades witnessed a fast growth and diversification of this new type of media. Some of the more resounding names are Christian Thomasius's (1655-1728) Monatsgespräche (Monthly Discourses, 1688-90, Halle/Saale), the first learned journal in German; the Neuen Zeitungen von gelehrten Sachen (News about Academic Matters, 1715), published in Leipzig; the Hamburger unpartheyischer Correspondent (Hamburg Impartial Correspondent; 1721-1934); and the Göttingische gelehrte Anzeigen (Göttingen Learned Advertisements).

\section{The Göttingische Gelehrte Anzeigen}

The Göttingische gelehrte Anzeigen (henceforth, the Anzeigen) is the oldest German learned journal still being published. ${ }^{20}$ It was initially established as a review journal: even though it did contain some short articles, essays and news sections about cultural life in Europe's metropolises, obtained from correspondents abroad or sieved from journals, magazines and pamphlets imported to Germany, the bulk of the roughly 1,100 pages per yearly volume was made up of literary reviews, varying widely in length, intensity and style. ${ }^{21}$ All texts were written in German, but the reviewed works covered the whole range of European literary products deserving of the attention of scientific minds or of those with a

19 Willenberg, Distribution und Übersetzung, 157-318.

20 The Göttingische gelehrte Anzeigen changed its title twice, from Göttingische Zeitungen von Gelehrten Sachen (1739-1752) to Göttingische Anzeigen von Gelehrten Sachen (1753-1801) and then in 1802 to its present name: Göttingische gelehrte Anzeigen. For convenience, its present name is used throughout the article; bibliographical references to the Anzeigen are abbreviated 'GGA', followed by the date and page range, and then the reviewer's surname in brackets, where it is known.

${ }^{21}$ In the eighteenth century, each yearly volume, delivered to its subscribers in 150-250 instalments over the course of the year (3-5 per week), contained c. 1,100 pages, give or take 200 . 
sense of culture. Thus, the Anzeigen offered a mixture of eighteenthcentury academia: theology, philosophy, literature, medical science, politics, history, maths, economics, geography, travels, agriculture, physics, biology and botany - and, of course, law.

The first issue of the Anzeigen was published in 1739, only a few years after the founding of the Georgia Augusta, the University of Göttingen (formal inauguration: 1737). From the very beginning, the journal was closely connected to the University and, a few years into its existence, also became tied to the Akademie der Wissenschaften zu Göttingen (Göttingen Academy of Sciences). ${ }^{22}$ The Academy was founded in 1751 by the British king George II - who was, of course, also the elector of Hanover and the founder of Göttingen University. Seen from the perspective of this article, both bonds proved to be decisive influences: the Anzeigen not only maintained close ties with one of the hubs of academic life in eighteenth-century Germany, the Academy, ${ }^{23}$ but could also make full use of the well-stocked shelves of the university library. Due to the close connections with Great Britain, the library of Göttingen University soon gained a reputation for maintaining the best collection of books from or on Great Britain in all the German-speaking territories. ${ }^{24}$ Thus, the Anzeigen became one of the principal means of transmission for knowledge about Britain in eighteenth-century Germany.

\section{English Law in the Anzeigen}

From the start, the Göttingen journal featured not only the regular reports from London and Oxford, but also a healthy dose of reviews of

22 Regarding the early years of the Anzeigen and the close connections with the University and particularly with the Academy, see J. Ringleben, 'Über die Anfänge der Göttingischen Gelehrten Anzeigen', in R. Smend and H.-H. Voigt (eds.), Die Wissenschaften in der Akademie. Vorträge beim Jubiläumskolloquium der Akademie der Wissenschaften zu Göttingen im Juni 2000 (Abhandlungen der Akademie der Wissenschaften zu Göttingen, Philologisch-Historische Klasse, 247 Dritte Folge; MathematischPhysikalische Klasse, 51 Dritte Folge; Göttingen, 2002), 345-55.

23 Ibid., 348-55.

${ }^{24}$ F. Ranieri, 'Eine Begegnung mit dem Common Law an der Universität Göttingen Mitte des 18. Jahrhunderts. Zur "Commentatio iuris exotici-historica de iure communi Angliae. Of the Common Law of England" von Christian Hartmann Samuel Gatzert', in M. Wittinger, R. Wendt and G. Ress (eds.), Verfassung - Völkerrecht - Kulturgüterschutz: Festschrift für Wilfried Fiedler zum 70. Geburtstag (Berlin, 2011), 931-53, at 938. 
British books, taking up about 5-10 per cent of each volume. ${ }^{25}$ Some of these deal with legal literature. In the 1742 issue, for example, we find three reviews of English law books:

- 'Bibliotheca Legum: or a new and compleat list of all the Common and statute Law Books of this Realm, from their first Publication to the Year 1740. under proper Heads: compiled by John Worrall' (5th edition $)^{26}$

- 'Repertorium iuridicum, or an Index to all the Cases in the Rear-Books [sic], Entries, Reports and Abridgments in Law and Equity, with an alphabetical Table of the Titles referring to the Cases, by a Barrister of Middle Temple' $(1741)^{27}$

- 'Iura Ecclesiastica, or a Treatise on the ecclesiastical Laws and Courts, by a Barrister of the Middle Temple' (1742). ${ }^{28}$

These three articles from the 1742 issue are not quite representative of other issues of the 1740s, 1750s and 1760s; most contain fewer. Nevertheless, measured against the overall number of English books imported into Germany in those years - 155 books by $1769,{ }^{29}$ of which only a fraction would be dedicated to legal subjects - quite a substantial number of those books coming to Germany in any given year and dealing with English law would probably have been reviewed in the Anzeigen.

This leads to another observation for which the 1742 issue stands as pars pro toto: the reviews are usually dedicated to quite recent literature. The three English law books reviewed in the 1742 issue had been published between 1740 and 1742 . This not only illustrates the review policy of the Anzeigen, aiming at timeliness, but also bears witness to the reviewers' access to the very latest literature - an observation which is true not only for reviews of English books but also in general.

All the texts were published anonymously, and it is not always possible to identify with precision the author of a particular review in the early issues of the Anzeigen. However, there are two important tools for lifting the veil of anonymity: contemporary ascriptions and hints in the reviews themselves.

25 Willenberg, Distribution und Übersetzung, 144. In the course of the eighteenth century, the Anzeigen reviewed probably as many publications in English as in French.

26 GGA 1742, 90-1. The year of publication is not given in the review; the fifth edition of the Bibliotheca legum was published in 1740.

27 GGA 1742, 250.

28 GGA 1741, 650-1.

29 Willenberg, Distribution und Übersetzung, 144. 
The first of these tools - contemporary ascriptions - can be found in a particular set of Anzeigen-volumes held by the Göttingen Academy. The early issues (1760-1803) of what used to be an archival or working copy have handwritten annotations in the margins. A series of later commentators scribbled authors' surnames next to most reviews. ${ }^{30}$ In the vast majority of cases the marginal glosses are correct, as these notes were meant to supplement the text of the Anzeigen for the administrative and archival purposes of the Academy, and were in all likelihood compiled using accounting books detailing not only the authors' fees but also their names. ${ }^{31}$ Furthermore, in many instances these names can be doublechecked using respective notes in other personal copies of leading staff members of the Anzeigen. ${ }^{32}$ Even if any doubts should remain, at the very least these ascriptions offer hints at the persons whom contemporaries thought were capable of writing the review in question. ${ }^{33}$

If these entries are to be trusted, then, for example, the review of William Blackstone's Commentaries on the Law [sic] of England, published on 23 January $1769,{ }^{34}$ is ascribed to a certain 'Seybert' - that is, Phillip Heinrich Seybert (1743-69), professor of law in Göttingen, who was, at the time of publication, twenty-five or twenty-six years old and not yet known as an aficionado of English law. ${ }^{35}$ The review is a relatively long one, comprising sixteen pages, and it is the longest one on British legal literature in the Anzeigen issues between 1739 and $1775 .{ }^{36}$

${ }^{30}$ On these commentators, see W. Schimpf (ed.), Die Rezensenten der Göttingischen Gelehrten Anzeigen 1760-1768. Nach den handschriftlichen Eintragungen des Exemplars der Göttinger Akademie der Wissenschaften (Arbeiten aus der Niedersächsischen Staatsund Universitätsbibliothek Göttingen, 18; Göttingen, 1982), 8-9.

31 Ibid., 9-10.

32 On these additional sources, see ibid., 7.

33 The ascriptions are gathered in two publications, which are therefore indispensable tools for working with the early issues of the Anzeigen: Schimpf (ed.), Rezensenten; O. Fambach (ed.), Die Mitarbeiter der Göttingischen Gelehrten Anzeigen 1769-1836. Nach dem mit den Beischriften des Jeremias David Reuß versehenen Exemplar der Universitätsbibliothek Tübingen (Tübingen, 1976).

${ }^{34}$ GGA 1769, 89-104.

35 Philipp Heinrich Seybert is an elusive figure; there is no modern biography. For scattered biographical remarks, see Archiv für Geschichte des Buchwesens, 39 (1993), 35-6; H. J. Baumann, Die Seyberths. Bilder zur Geschichte einer Nassauischen Familie (Wiesbaden, 1989), 26. For contemporary remarks see GGA 1769, 561 (Michaelis) (Seybert made 'Professor juris extraordinarius' in Göttingen); GGA 1769, 1114 (Kästner) (short obituary).

${ }^{36}$ On 14 October that same year, 1769, Seybert would pass away, and one cannot help but wonder whether he would have made more use of this, as it came to pass, singular 
Two other names deserve a mention as mid-eighteenth-century reviewers of works on English law: Christian Hartmann Samuel Gatzert $(1739-1807)^{37}$ and Justus Claproth (1728-1805). ${ }^{38}$ Both illustrate the second approach for identifying authors of reviews - clues in the texts themselves - while at the same time showing the limitations of such deductions.

In October 1765, a longer review was published in the Anzeigen, dealing in some detail with Gatzert's work De iure communi Angliae. ${ }^{39}$ Unusual for a treatise by a German, it bore an English subtitle - Of the Common Law of England - and, according to an explanatory addition to the title, Gatzert's work was a historical-literary commentary of foreign law (Commentatio iuris exotici historico-litteraria). ${ }^{40}$ The book had been published in Göttingen in the same year as its review - 1765 - and was written in Latin. It explains the sources of English Common law, then dedicates about a quarter of its 103 pages $^{41}$ to its history, followed by an account of the applicability of 'jus Romanum' in England, and lastly points to some helpful bibliographical tools. Along a double track of a historical 'Who's who' of English jurisprudence - from Glanvill and

advance into English Common law and whether he would have ventured deeper into the subject.

37 On Gatzert, see F. Knöpp, 'Gatzert, Hartmann Freiherr von', in Neue Deutsche Biographie, vol. VI (Berlin, 1964), 91-2, available at www.deutsche-biographie.de/ pnd116466405.html\#ndbcontent; J. R. Dieterich, 'Ein Gießener Professor als hessischer Staatsminister', Archiv für hessische Geschichts- und Altertumskunde, Neue Folge 5 (1907), 462-514; W. Huschke, 'Die Herkunft des hessen-darmstädtischen Staatsmanns Christian Hartmann Samuel von Gatzert (1739-1807)', Archiv für Familienforschung, 5(3) (2001), 164-77 ${ }^{1}$; Ranieri, 'Eine Begegnung mit dem Common Law', 932-4; S. Jahns, Das Reichskammergericht und seine Richter. Verfassung und Sozialstruktur eines höchsten Gerichts im Alten Reich, Teil II: Biographien (Quellen und Forschungen zur Höchsten Gerichtsbarkeit im Alten Reich, 26; Cologne, 2003), 1304-12.

38 Sometimes also spelled 'Clapproth'. On Claproth, see W. Henckel, 'Göttinger Lehrer des Konkursrechts im 18. Jahrhundert', in F. Loos (ed.), Rechtswissenschaft in Göttingen. Göttinger Juristen aus 250 Jahren (Göttingen, 1987), 100-22; B. Mertens, Gesetzgebungskunst im Zeitalter der Kodifikationen. Theorie und Praxis der Gesetzgebungstechnik aus historisch-vergleichender Sicht (Tübinger Rechtswissenschaftliche Abhandlungen, 98; Tübingen, 2004), esp. 288-90, 331-3, 337-9, 314 and 387-8, 442, 444, analysing the influence Claproth's draft legislation (Ohnmasgeblicher Entwurf eines Gesetzbuches, 3 vols. (Frankfurt am Main, 1773-6)) exerted on late eighteenth-century thinking about codification and the development of legislative techniques in Germany.

39 GGA 1765, 1017-26.

40 On this treatise, see Rüfner, 'Continental Jurists and English Common Law', 627-8, 634; Ranieri, 'Eine Begegnung mit dem Common Law'.

41 As well as an introduction (eight pages) and a table of contents (two pages). 
Bracton via Littleton and Coke to Blackstone - and a diachronic bibliographical cross-cut, Gatzert's treatise travels through six-hundred years of English legal history. It concludes by addressing some of the institutions of English law, such as the 'scholae et Collegia Iureconsultorum'42 and the serjeants-at-law. ${ }^{43}$ De iure communi Angliae is a bird's eye view of the contemporary English legal system and its sources, along with an äußere Rechtsgeschichte. Substantive and procedural law are scarcely mentioned.

Gatzert can thus be credited with the first comprehensive treatise on English law from a German quill. ${ }^{44}$ At the time of publication, Gatzert was professor of law in Göttingen. In late 1762, he had spent some time in England. ${ }^{45}$ The biographical-bibliographical part of his treatise in particular suggests that he had used this time to access libraries and to study English legal literature. Still, little can be said about Gatzert's knowledge of substantive and procedural English law; in all probability it remained uncertain at best.

Given the author's assumed modest knowledge of English law, his choice of topic seems strange, maybe even unfortunate. From the point of view of English jurists - and the English subtitle was probably meant as an advertisement directed at them as well as a display of linguistic skills - it merely was a miscellany of well-known facts, biographicalbibliographical data and a summary of Common law Wissenschaftsgeschichte. As such, it must have been of no concern to them. At the same time, it lay far off the dogmatic ambit of German legal academia and forensic practice, as it was especially remote from the ius commune and the regional ius particulare. Only its account of legal sources, methods and the applicability of Roman law could have interested a wider readership. Nevertheless, Gatzert's De iure communi Angliae is more than a mere product of leisure time during his stay in England. Its aim and the readership he had in mind are discernible from

42 C. H. S. Gatzert, De iure communi Angliae: Of the Common Law of England (Göttingen, 1765), $77-84$.

43 Ibid., 84-6.

44 The few treatises by German authors on subjects of English law published earlier include, for example, J. A. Gerhard and O. Schulte, Discursus publicus de jura ac potestate parlamenti Britannici (Jena, 1660), and G. H. Ayrer, Orationes binae, [...]; iuncta est De sublimi sacri cognationis tribunali Anglis, The Court of the Lord High Stewart dicto, prolusio inauguralis (Göttingen, 1744); for a review of the latter, see GGA 1746, 684; a short notice concerning a reprint ('Ge. Henr. Ayreri D. Opuscula minora [...]', vol. II, 1747) can be found in GGA 1747, 373.

45 Gatzert, De iure communi Angliae, 94 n.: 'Memini in diurnis Londinensibus circa finem anni 1762'. The details of this stay in England are hazy, the duration uncertain. 
Gatzert's further activities in Göttingen, announced by the university calendar for the winter term 1764/5 as published in the Anzeigen:

Herr Doctor Gatzert will read privatissime for the English residing here the pure jurisprudence of Roman private law, along with the necessary antiquities, in the Latin language; and in doing so he will, as far as possible, point to the most important deviations of English and Scottish private law; the particulars of the structure of which lecture he will announce in a special Programmate. ${ }^{46}$

Thus, Gatzert attempted to establish a form of lecture or seminar on English Common law at Göttingen University. The book was meant as a primer or a textbook supporting this lecture. ${ }^{47}$ Taking into account its aim to lay foundations in the novel field of English Common law, together with the comprehensive guide to English legal literature, it can also be read as an encouragement and manual for further research in that area. Gatzert gave the lecture only once, as announced in the winter term of 1764/5, shortly before he published his De iure communi Angliae. But contrary to the announcement in the university calendar, he gave it 'anglicano sermone', that is, in English, as he himself noted in the introduction to his De iure communi Angliae. ${ }^{48}$ Perhaps due to the choice of classroom language, no German was attracted by the ius exoticum, to quote the sub-title of Gatzert's book: his only two students were British 'Anglo altero, altero Scoto,' that is, 'an Englishman the one, the other a Scotsman'. ${ }^{49}$

The lecture-plans failed, as had the book. Soon after publication, Gatzert's De iure communi Angliae seems to have been all but forgotten. When, at a later point in the nineteenth century, the study of English law

46 'Die reine Römische bürgerliche Rechtsgelartheit nebst den nöthigen Alterthümern wird Herr D. Gatzert den hier befindlichen Engelländern privatissime in lateinischer Sprache lesen; und dabey die wichtigsten Abweichungen des Englischen und Schottischen Privatrechts so viel als möglich anzeigen; von welchen Vorlesungen er die nähere Einrichtung in einem besondern Programmate bekannt machen wird'; GGA 1764, 852. Ranieri, 'Eine Begegnung mit dem Common Law', 941-2.

${ }^{48}$ Gatzert, De iure communi Angliae, Introductio, 3-4: 'Proximam scriptioni ansam Iuris Romani ab eoque diuersi Anglici Scoticique Collegium praebuit, quod anglicano sermone per elapsum semestre hibernum cum pari juuenum praeclarae indolis speique optimae, litteris apud nos laudabili opera vacantium, rogatus habui, Anglo altero, altero Scoto. Ea autem in re ita processi, ut ad Heineccii Institutionum librum, Bretonibus aeque magni ac nostratibus aestimatum, scholas meas instituerem, iisque semper in locis, ubi ipse doctrinae cujusuis usum Germanicum subjunxit, Anglicanum ego et Scoticum substituerem.'

49 Ibid., Introductio, 3-4. 
in Germany gathered momentum, none of the authors then involved was acquainted with Gatzert's work. ${ }^{50}$

Nevertheless, in 1765 this was all still in the future, and Gatzert seems to have been quite intent on giving his De iure communi Angliae all the publicity he thought it deserved: the anonymous review published in the Anzeigen is a concise summary of De iure communi Angliae. It describes its structure and repeats its main findings, all the while stressing the novelty of Gatzert's work. Not only that, but it is full of praise for the book and even goes on to repeat the expression of gratitude contained in the first pages of De iure communi Angliae for Gatzert's noble patron: 'the grace, which can never be praised enough, and the tireless munificence of our illustrious and gracious Curator, his excellency, the Herr prime minister Freyherrr von Münchhausen'. ${ }^{51}$ It is highly unlikely that anyone but Gatzert himself wrote the review of his book. This assumption is confirmed by a commentary in the annotated Anzeigen copy of the Academy: in the margin next to the head of the review there is a note stating 'Gatzert'.

Much the same can be said of the work and career of Justus Claproth. Claproth was not only a professor of law in Göttingen - where he would spend the rest of his academic career - from 1761, but he took a deep interest in foreign literature and its translation. Aside from his more wellknown work on Voltaire, he partially translated William Blackstone's Analysis of the Laws of England (4th edition, 1759) into German. ${ }^{52}$ The review of Claproth's translation was published in the Anzeigen in July $1769,{ }^{53}$ and thus coincides with the publication of the translation. It repeats parts of Claproth's introduction to the translation verbatim. Claproth limited his translation to those passages from Blackstone's 'Analysis', which must have been most relevant to Continental jurists, as the passages related to the study of English law, the history of Roman law in England and the opinions English jurists had of Roman law. Very much like Gatzert's De iure communi Angliae, Claproth guided Continental jurists towards the more easily digestible parts of the

${ }^{50}$ Ranieri, 'Eine Begegnung mit dem Common Law', 952.

51 'die nie genug zu preisende Gnade und unermüdliche Freygebigkeit unsers erlauchten und huldreichen Curators, des Hrn. Premierministers Freyherrn von Münchhausen Excellenz'; GGA 1767, 1026.

52 J. Claproth, Der neueste Zustand der Rechtsgelehrsamkeit in Engelland. Aus dem Englischen übersetzt von Justus Claproth [...] (Göttingen, 1767).

${ }^{53}$ GGA 1767, 705-8. 
English legal system. The anonymous reviewer addresses the reasons for this careful approach:

As this treatise [i.e. Blackstone's Analysis of the Laws of England] is a woven fabric of English artificial terms, which, moreover, wholly depart from the language of Roman, Longobardic and German law, it will, for a foreigner, be quite difficult to produce a good translation. ... Out of such important considerations, Herr Professor Claproth has drafted both pieces in our native tongue in a very natural manner; has, quite a few years ago, read these in our local German society; and now ... has had them printed. ${ }^{54}$

Again, the review shows such intimate knowledge of the translation and is so full of praise that it, too, smacks of the translator himself merely giving it an interpretatio authentica. Nevertheless, according to the marginal note in the Anzeigen copy held by the Göttingen Academy, this is not an instance of Claproth imitating Gatzert's attempt at selfadvertisement. Rather, the reviewer is identified as Philipp Heinrich Seybert. The similarities between the review itself and the work under review are therefore misleading; but perhaps, at the same time, a nascent review-circle begins to emerge.

Seybert, Gatzert and Claproth would have all had different motives for reviewing books on English law. Perhaps they even represent different types of importers of legal knowledge in the German-speaking area around the mid-eighteenth century. Seybert's reasons for reviewing Blackstone's opus magnum are, as of now, not discernible, although the following notice in the Anzeigen of 16 October 1769 could contain a hint:

On 14 October, Prof. Juris extraordinarius, Philipp Heinrich Seybert, has died of a haemorrhage, after having returned only shortly earlier from a learned journey. It is he who has, in this year, penned all, and in the year before some of the legal contributions of our Anzeigen. And our readers will now for themselves judge his merits, and what could have been expected from him, had providence granted him a longer life. ${ }^{55}$

54 'Da diese Schrift [sc. Blackstone's Analysis of the Laws of England] ein Gewebe von englischen Kunstwörtern ist, die überdies von der Sprache des römischen, longobardischen und teutschen Rechts ganz abweichen; so wird es für einen Ausländer ziemlich schwer seyn, eine gute Uebersetzung zu liefern. ... Aus so wichtigen Gründen hat der Hr. Professor Claproth beyde Stücke, in unserer Muttersprache sehr natürlich abgefaßt, dieselben schon vor etlichen Jahren in der hiesigen teutschen Gesellschaft vorgelesen, und nun ... drucken lassen'; GGA 1767, 705-6.

55 'Am 14ten October ist der Prof. Juris extraordinarius, Philipp Heinrich Seyberth, an einer Blutstürzung gestorben, nachdem er nur erst kurzens von einer gelehrten Reise 
Perhaps this journey had led Seybert to, among other destinations, Great Britain, and perhaps he had acquired there the necessary academic equipment to engage in an English-German legal dialogue after his return to Göttingen.

Claproth, however, combined legal expertise with linguistic skills and an enthusiasm for translation. The third, and perhaps the most knowledgeable person with regard to the English legal system, Gatzert, followed a more ambitious scheme of introducing English Common law as a subject into the curriculum at Göttingen. The review of his 'course material', so to speak, can be viewed as a means of propaganda. As a side note, this propaganda piece ended with a cliffhanger: 'By the way, whether Hr. Pr. will continue to work on this arduous path of the British law in the future, we cannot say at this point of time. ${ }^{56}$

Despite differing motivations, Seybert, Claproth and Gatzert had some things in common. Firstly, and rather obviously, they were all working in Göttingen. Even though the Anzeigen drew their reviewers from other academic centres of the German territories as well, most of the contributors worked in Göttingen or nearby. ${ }^{57}$ Secondly, their main areas of academic interest lay elsewhere: Claproth published on procedural law, insolvency law and contract law; Gatzert, although he later held state offices in Hesse, penned his academic works primarily on the fields of ius

zurückgekommen war. Er ist es, von dem in diesem Jahre alle, und vorhin einige juristische Artikel unserer Anzeigen kamen: und unsere Leser werden nunmehr selbst über seine Verdienste, und was von ihm zu erwarten gewesen wäre, wenn ihm die Vorsicht ein langeres Leben geschenkt hätte, urtheilen'; GGA 1769, 1114 (Kästner).

56 'Ob übrigens der Hr. Pr. auf dieser mühsamen Bahn der Britannischen Rechte ferner zu arbeiten fortfahren werde, können wir noch nicht sagen'; GGA 1765, 1026.

57 The 1767 issue, for example, contains 597 contributions by 13 different authors (Johann Christoph Gatterer, Christian Hartmann Samuel Gatzert, Albrecht von Haller, Christian Gottlob Heyne, Abraham Gotthelf Kästner, Gottfried Leß, Johann David Michaelis, Johann Andreas Murray, Johann Philipp Murray, August Ludwig Schlözer, Philipp Heinrich Seybert, Friedrich Wilhelm Stromeyer and Christian Wilhelm Franz Walch); see Schimpf (ed.), Rezensenten, 55-61. Out of these thirteen, eleven worked in Göttingen in 1767 (Gatzert left Göttingen for Giessen in the course of 1767). The remaining two also had very close connections to Göttingen: von Haller (Berne) had been a professor of medicine at the University of Göttingen (1736-53) and had also been the driving force behind the Anzeigen in its early years, while Schlözer, working in St Petersburg in 1767, would become a professor for the history of Russia in Göttingen two years later (1769). For an overview of their respective contributions to the Anzeigen, see Schimpf (ed.), Rezensenten, 80-97. 
publicum, deutsches Privatrecht and feudal law; ${ }^{58}$ Seybert had written on tontines. ${ }^{59}$ The opportunities of Göttingen thus united legal scholars from very different paths and directed some of their efforts towards English law.

It is clear that at least Claproth and Gatzert discussed their respective views of English law. Their common approach of choosing comparatively easily intelligible topics - aspects of the foundations and framework of the English legal system, like sources, institutions and scholars - as well as, by and large, leaving out substantive and procedural English law suggests as much. A clearer indication can be found in Gatzert's De iure communi Angliae: in a footnote to William Blackstone's works Gatzert thanks his 'Fautor et Collega aestumatissimus [patron and highly esteemed colleague] ... Claprothius noster' for 'benevolent talks' ${ }^{60}$

We can imagine that for a short period of time Seybert, Gatzert and Claproth discussed their peculiar visions of English law over a puff on the pipe and a glass of port. But after this brief survey of reviews of English legal literature, it is to be suspected that around the middle of the eighteenth century there were not many more Anglophile circles in Germany debating the hitherto rather unknown legal world of the British Isles.

That the enthusiasm of a small number of individuals, like the academic trefoil Seybert, Gatzert and Claproth, started to fill a blank space, may be illustrated by flipping through the pages of the most important German encyclopaedia of the eighteenth century, Zedlers UniversalLexicon, which fills four metres of shelf-space. A quick search for those lemmata behind which one could reasonably expect entries on English law produces a meagre harvest: there are very short entries under 'Bracton', 'Juries', 'King's Bench' and 'court', ${ }^{61}$ but nothing on, for example, 'englisches Recht', 'writ', 'Common law', 'Legibus', 'chancery' or 'equity'. Thus, even the most ambitious encyclopaedic project of the day had little interest in English law. Humble as Seybert's contributions

58 Ranieri, 'Eine Begegnung mit dem Common Law', 933 n. 7.

59 P. H. Seybert, De reditu annuo praesertim vitali tontina ac fiscis viduarum (Göttingen, 1767); review: GGA 1767, 1225-7 (Kästner).

${ }^{60}$ Gatzert, De iure communi Angliae, 59 n. 2.

${ }^{61}$ J. H. Zedler, Grosses vollständiges Universal-Lexikon, vol. III: King's Bench (Halle/Saale and Leipzig, 1733; repr. Graz, 1994), cols. 311-12; vol. IV: Bracton (Halle/Saale and Leipzig, 1733; repr. Graz, 1994), col. 796; vol. VI: Court (Halle/Saale and Leipzig, 1733; repr. Graz, 1994), col. 1487; vol. XIV: Juries (Leipzig and Halle/Saale, 1735; repr. Graz, 1995), cols. 1670-1. 
as a reviewer, Claproth's translation of Blackstone and Gatzert's De iure communi Angliae, along with the latter's review of his own work may be, all three Göttingen academics were, in their own ways, trailblazers for a broader German academic interest in English Common law.

After this glance at their authors, some light shall now be cast on the reviews themselves. A few common aspects come to light regarding language, use of literature and contents. Reading the reviews, it soon becomes obvious that English proved to be a formidable linguistic barrier for many German scholars. The reviewers stress the need for translations time and again, and their comments on linguistic issues highlight their difficulties: the jumble of then-modern English on the one hand and law French on the other - a professional terminology not based on the Latin legal lingua franca of the ius commune - added to some Latin texts on English law for spice, all taken together became too much for German scholars. For example, in his treatise De iure communi Angliae, Gatzert complained about the 'unfortunate mixture of Latin, Norman and Saxon words $^{362}$ that he had to confront - a complaint repeated in his review of De iure communi Angliae by pointing to the 'adventurous and un-English English legal language, the barbarism of which had already with our forebears brought about the saying that an English legal academic stops being an academic outside of England' ${ }^{63}$ Gatzert continued: 'The barbarism of the language must, even with the help of many and good dictionaries, cause in each and every one revulsion against this labyrinth of law, that ... he has to enter without any guidance. ${ }^{64}$

What kind of English legal texts are referenced in the Anzeigen? The answer is a collection which can perhaps best be described as the 'catch of the day'. If one looks at the time roughly between 1739 and 1775, one will see Blackstone's commentaries next to a bundle of judgments on the reprinting of books, ${ }^{65}$ Gatzert's treatise De iure communi Angliae, collections of reports, works on ecclesiastical law in England and The Statutes

62 Gatzert, De iure communi Angliae, 66 n.; further: 'linguae anglicanae juridicae barbarie' (91).

63 'abentheuerliche und unenglische Englische Rechtssprache, deren Barbarey schon bey unsern Vorfahren das Sprüchwort verursacht hat, daß ein englischer Rechtsgelehrter ausserhalb England aufhöre, ein Gelehrter zu sein'; GGA 1765, 1022.

64 'Die Barbarey der Sprache, so viele und gute Wörter-Bücher auch vorhanden sind, muß bey einem jeden doch einen Abscheu gegen dieses Rechtslabyrinth erregen, in das er sich noch dazu ohne Führer wagen muß'; GGA 1765, 1024-5.

${ }^{65}$ GGA 1775, 346-50 (Kästner). 
at Large. ${ }^{66}$ The subject receiving the largest proportion of reviews was constitutional law, alongside related areas; ${ }^{67}$ criminal law is rarely touched upon. ${ }^{68}$ A common feature is the rather recent publishing date of the texts. Apart from that, it is hard to make out any consistent guidelines for choosing reviews; even the lengths vary considerably. ${ }^{69}$ The library of Göttingen University offered a decent but limited collection of British books, and due to a lack of English skills, the circle of potential reviewers would have been small. Therefore, it is quite probable that the Anzeigen was not picky and published reviews on any English legal material offered. ${ }^{70}$ This impression is supported by the particular

${ }^{66}$ GGA 1759, 171-2: 'The Statutes at Large from magna Charta to the seventh Year of King George the Second'.

${ }^{67}$ For example, GGA 1739, 631-4: 'An historical and political Discourse of the laws and Government of England from the first times, to the end of the reign of Queen Elizabeth. With a vindication of the ancient way of Parliaments in England. Collected from some Manuscript notes of John Selden, Esq. by Nathanael Bacon, of Grays-Inn, Esq. the fourth edition, corrected and improved by a Gentleman of the Middle-Temple'; GGA 1740, 162-3: 'A collection of State-papers of John Thurloe, Esq [... ]'; GGA 1741, 473-4: 'Ius Parliamentarium: or the ancient Power, Iurisdiction, Rights, liberties aud [sic] Privileges of the most High Court of Parliament [...] By W. Petyt [...] 1741'; GGA 1745, 293-4: 'Thomæ Rymeri Fœederibus \& actis publicis Anglicanis' (parts 9 and 10); GGA 1746 (423-4): 'M. Samuel Squire Archidiaconus [...] a. 1745 [...] An enquiry into the foundation of the English constitution \&c. oder Untersuchung der Anfänge der Englischen Staatsverfassung'; GGA 1747, 442-4: 'Histoire du Parlement d'Angleterre par M. l'Abbé Raynal'; GGA 1747, 572: 'the history and Proceedings of the house of commons during the last parliament'; GGA 1749, 629-30: 'The patriots miscellany'; GGA 1748, 554: 'Johann Strype [...] Abdrigment of the public treaties'. Many related titles focus more strongly on current politics or political history, for example GGA 1743, 417-18: 'Parliamentary Debates and Proceedings, both of the Lords and Commons' (21 vols.); GGA 1742, 618: 'Monarchy asserted to be the best, most ancient and Legal Form of Gouernment. 1742'; GGA 1743, 138-9: 'The History and Proceedings of the House of Lords, from the Restoration in 1660. to the present Time [. . .], voll. [sic] VII'; GGA 1747, 628-9: 'Liberty and Right'; GGA 1747, 506: 'Determinations of the honourable house of commons concerning Elections'; GGA 1747, 507: 'Orders, resolutions and determinations of the honourable house of Commons'; GGA 1748, 877: 'the whole proceeding and trial in the honse [sic!] of Peers against Simon Lord Lovat' (also in GGA 1748, 171); GGA 1748, 619: 'A comment on M. Warb. Alliance between church and state'.

${ }^{68}$ GGA 1747, 572: 'The law of Arrests'; GGA 1772, 1266-7 (Feder): 'Principles of penal law. The second edition 1771'.

69 Seybert's review of Blackstone, for example, runs for a stunning sixteen pages, while the Repertorium iuridicum has to make do with fourteen lines.

${ }^{70}$ For example, on matters as diverse as courts (GGA 1747, 611: 'Rules orders and notices in the court of Kings Bench'; GGA 1748, 629: 'Theodor Barlow, ein Rechtsgelehrter in Middle Temple, hat [...] drucken lassen The justice of peace'), bankruptcy (GGA 1743, 145-6: 'The Law for and against Bankrupts containing all the statutes, Cases at large, Arguments, Resolutions, Judgments and Decrees under the Head of Bankruptcy down to 
culture of discussion: the works under review are never placed into a legal discourse. They lack references to other books, legal developments, judicature or protagonists, and are thus denuded of their context. It is therefore likely that the reviewers worked with very limited literary sources at hand and would rarely, if at all, have consulted any other book than the one under review. ${ }^{71}$

Content-wise, all reviews remain superficial. It is quite apparent that the reviewers do not really know their way around contemporary English law. ${ }^{72}$ Their contributions are restricted to - albeit sometimes almost metaphorical - descriptions of an utterly foreign landscape. Claproth, for example, is obviously confused by the English system of legal education. Instead of clearly explaining the function of the Inns of Court in English legal education, he awkwardly calls them 'collegial orders' and 'juristic monasteries', ${ }^{73}$ and does not explain the relationship of the education provided by these Inns to that provided by the universities of Oxford or Cambridge, which offered degrees in Civil or Canon law.

Gatzert's De iure communi Angliae shows that he had a far clearer idea of the English legal education and a career in law in England. Nevertheless, it is highly unlikely that many German readers, even those educated in law, would have understood what Gatzert meant when, in all brevity, he informed them about the importance of the Vinerian endowment: 'Thus, Carl Viner ... by these means attempted to remedy the shortcomings of the university. Because regularly, the Englishman will learn his law at London from the practice in the Temple. ${ }^{74}$

the present Time. By a late Commissioner of Bankrupts') and bills of exchange (GGA 1760, 679 (Selchow?): 'the law of bills of Exchange, promissory notes, Bank-notes and Insurances [...] by a Gentleman of the Middle Temple').

${ }^{71}$ Gatzert's De iure communi Angliae is the one exception to the rule that in all probability the reviewers will have read few to no other works on English law; see Ranieri's meticulous analysis of the books consulted by Gatzert while writing De iure communi Angliae: Ranieri, 'Eine Begegnung mit dem Common Law', 941-9.

72 Only a few books on Scottish law are treated: GGA 1742, 153: 'Thomae Cragii de Riccartoun [...], ius feudale, tribus libris comprehensum. Editio tertia, prioribus multo emendatior, opera \& Iacobi Baillie, aduocati 1741'. Some are to be seen against the backdrop of the recent Jacobite rising, such as GGA 1747, 195: 'Hereditary right not indefeasible'; GGA 1747, 525: 'An ample disquisition into the nature of regalities and other heretable jurisdictions in Scotland'; GGA 1747, 611: a note stating that documents concerning current proceedings against the former lord provost of Edinburgh, Archibald Stewart, have been published - to be continued along with the proceedings.

73 GGA 1767, 707-8: 'collegialische Orden', 'juristische Kloster'.

74 'Carl Viner vermachte, in seinem letzten Willen, der vom 29sten Dec. 1755 datirt ist, 12000 Pfund (72000 rthlr. [sc. Reichstaler] guten Geldes), eine Profeßion des gemeinen 
A similar reservation can be felt when English courts are mentioned in the reviews: courts of Common law are sometimes spoken of, though not very often, and they are almost never explained. If one consults the review of the Repertorium iuridicum, one can read the following:

The author has taken pains to note all court cases, from the times of Edward I until the present day, which he has been able to find - partly in the laws [Gesetzen], partly in the cases, partly in a tremendous amount of books - and to attach their decisions, distinguishing between those reached according to the laws, and those according to equity [Billigkeit]. He has compiled around 40,000 quarrels, and with this he has put on the market English pandects. ${ }^{75}$

Referring to the pandects, the author uses a legal format familiar to all ius commune lawyers to describe the book at hand. Willingly or not, he would thus have stifled any appreciation of the peculiarities of English law and could have evoked a picture of the pandects not as one possible way among others to organise and structure legal sources, but rather as a literary constant of the legal world - to be found in England, too, if one only looked closely enough. ${ }^{76}$ Furthermore, the different branches of English law, that is, Common law in a stricter sense and equity, are interpreted as legislative acts (Gesetze) and equity (Billigkeit) - in all probability mirroring a ius commune understanding of strict law and aequitas rather than being a clear grasp of English law. ${ }^{77}$

Rechtes davon zu stiften, auch Stipendiaten, die sich auf das Recht legten, davon zu unterhalten: und suchte auf die Weise einen bisherigen Mangel der Universität zu ersetzen. Denn ordentlich lernt der Engländer sein Recht zu London aus der Praxi im Tempel'; GGA 1758, 1479 (Gatzert).

75 'Der Verfasser hat sich die Mühe gegeben, von den Zeiten Eduard I. an bis zu die jetzige Zeiten alle Gerichts-Händel zu bemerken, die er theils in den Gesetzen theils in den Gerichts-Handlungen theils in einer ungemeinen Menge von Büchern hat ausfündig machen können und ihre Entscheidungen theils nach den Gesetzen theils nach der Billigkeit beyzufügen. Er hat also auf 40000 Händel gesammlet und Englische Pandekten des Rechts hierinnen zu Markte gebracht'; GGA 1742, 250.

${ }^{76}$ A similar comparative use of Roman sources is found in GGA 1749, 268-9 ('The Grounds and rudiments of Law and equity'): 'It is the intention to bring the knowledge of the English Laws into a rule-based format, and to, so to speak, construct an English Digest for the advantage of teachers and students' ('Die Absicht ist, die Kenntniß der Enlischen [sic!] Rechte in eine Regelförmige Gestalt zu bringen, und so zu sagen einen Englischen Digest zum Nutzen der Lehrer und der Lernenden zu bilden').

77 Similarly GGA 1760,680 , on appeals to the 'Lord Canzler [...] who is the only judge in the whole realm entitled to decide a case without referring to a positive law, merely according to equity' ('Lord Canzler [...], welcher der einzige Richter im ganzen Reiche 
One focus of attention looms large, however: William Blackstone, or 'Wilhelm Blackstone. ${ }^{78}$ An issue of the Anzeigen published in December 1758 mentions the endowment of the Vinerian chair as well as the fact that the 'erste Vinerische Professor, Wilhelm Blackstone' had held his first lecture on 25 October $1758 .^{79}$ Why was there now such detailed news from Oxford in Göttingen? It is not unreasonable to view Claproth's 'juristic monasteries', as well as the news about the Vinerian chair and the reception of Blackstone's writings in the Anzeigen, as an attempt to bridge a deep chasm between English and German legal culture of the eighteenth century. German legal scholars of the eighteenth century were not only ignorant about substantive and procedural English law but also, perhaps more importantly, did not comprehend the English system of legal education. ${ }^{80}$

Neither the insight that jurisdiction established important ley lines for legal developments nor that it was a driving force behind the differentiation and the development of law was a novelty in the land of the Reichskammergericht (Imperial Chamber Court), nor was the fact that collections of cases and court decisions played an important part and had established themselves as a legal literary genre - a glance at the popular collections of decisions of the Reichskammergericht is proof of that. Even though English Common law also took into consideration acts, statutes and books of authority, the role of precedents and thus of case law was of a completely different quality. Therefore, even if the individual components of the English legal system were not foreign to Continental jurists, their respective importance, their role and their interaction followed, in the English context, very different rules. In the absence of introductory literature which did not set too high a linguistic barrier, and for want of first-hand experience gained within the English legal system, most German jurists of the mid-eighteenth century would neither have expected nor noticed this. German legal academics thought about law be it their own or foreign law - by using the tools and concepts of their own legal education: universities, curricula, relatively static and accepted

ist, so das Recht hat, ohne Anführung eines positiven Gesetzes bloß nach der Billigkeit zu sprechen [...]').

78 GGA 1758, 1480 (Gatzert).

${ }^{79}$ GGA 1758, 1479-80 (Gatzert). In a footnote of his De iure communi Angliae (79, n.), Gatzert himself mentioned having written this notice in the Anzeigen, and he goes on to repeat much of its contents, informing the reader of the background to the Vinerian endowment and some of its particulars.

${ }^{80}$ See Gatzert's complaint about 'difficultas studii'; De iure communi Angliae, 87-91. 
corpora of authoritative texts and learned efforts to systematise or at least to order the sources and rules of ius commune as well as ius particulare. It seems that against this backdrop, the institutional mooring of the university teaching of English law by way of the Vinerian chair had become a point of interest for German legal scholars. It was perhaps understood as a move towards Continental academic conditions and would certainly have facilitated understanding of the English legal system. The same holds true for William Blackstone's most impressive literary achievement as Vinerian professor, his Commentaries on the Laws of England. ${ }^{81}$ The ordering of the Common law material in four volumes, bearing titles which would have seemed familiar to ius commune jurists, offered a comprehensive textual focal point for the study of English law - in all of his Majesty's domains.

\section{German Learned Journals and English Law}

The Anzeigen offers insights into a legal learning process, although admittedly the issues consulted here (1739-75) contain but a trickle of information about English law and its books. But the limited quality and the idiosyncratic perspectives of these contributions must not belie two important points. Firstly, this trickle was carried by a powerful current: in the eighteenth century, issues of the Anzeigen were one of the prime interdisciplinary sources of information for academics in the Germanspeaking territories, not least due to their timeliness. Even though the intensity of the academic analyses of English law showed room for improvement, the place of the discussion was first class. Secondly, even though English lawyers and legal academics had since the Middle Ages been fully aware of ius commune and other Continental legal systems and laws, the opposite was not necessarily true. When looking at the mideighteenth century, we are observing the first cautious attempts of German legal academia to get to know English law. Thus, we accompany, in a manner of speaking, the exploration of legal terra incognita.

The Göttingische gelehrte Anzeigen is used here as an example. There are other important journals that would have helped to disseminate knowledge of English law in German-speaking areas over the course of the eighteenth century. Apart from those mentioned above, some of the special literary fields of activity and products of veritable Anglophilia

814 vols. (Oxford, 1765-70). 
seem to be rather promising candidates for further research, such as the Brittische Bibliothek (1756-67), the Britisches Museum für die Deutschen (1777-81) and the Annalen der Brittischen Geschichte (1789-1800). ${ }^{82}$ Thoroughly combing through a greater number of these publications might bring to light a sort of 'early reception' (Frührezeption) of English law taking place before the more rigorous, precise and better-informed scholarly attempts of the nineteenth century, and possibly paving the way for them.

82 On these journals, see Willenberg, Distribution und Übersetzung, 148-53. 